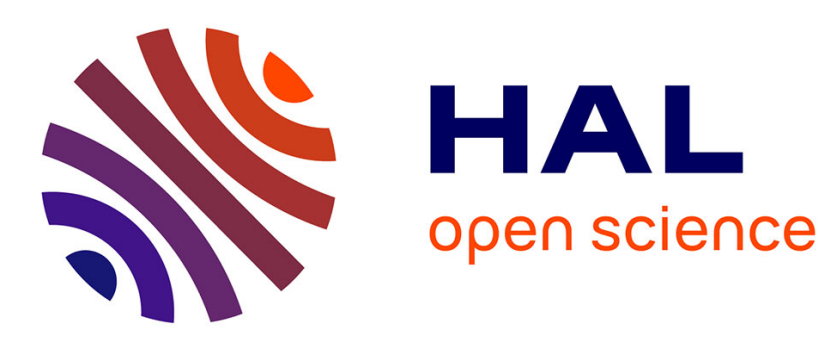

\title{
Role mechanisms and control of lactic acid bacteria lysis in cheese
}

\author{
Sylvie S. Lortal, Marie-Pierre Chapot Chartier
}

\section{To cite this version:}

Sylvie S. Lortal, Marie-Pierre Chapot Chartier. Role mechanisms and control of lactic acid bacteria lysis in cheese. International Dairy Journal, 2005, 16 (6-9), pp.857-871. 10.1016/j.idairyj.2004.08.024 . hal-02679333

\section{HAL Id: hal-02679333 https://hal.inrae.fr/hal-02679333}

Submitted on 31 May 2020

HAL is a multi-disciplinary open access archive for the deposit and dissemination of scientific research documents, whether they are published or not. The documents may come from teaching and research institutions in France or abroad, or from public or private research centers.
L'archive ouverte pluridisciplinaire HAL, est destinée au dépôt et à la diffusion de documents scientifiques de niveau recherche, publiés ou non, émanant des établissements d'enseignement et de recherche français ou étrangers, des laboratoires publics ou privés. 


\title{
Role, mechanisms and control of lactic acid bacteria lysis in cheese
}

\author{
S. Lortal ${ }^{\mathrm{a}, *}$, M.-P. Chapot-Chartier ${ }^{\mathrm{b}}$ \\ ${ }^{a}$ INRA, Laboratoire de Recherche de Technologie Laitière, 65 rue de Saint-Brieuc, 35042 Rennes Cedex, France \\ ${ }^{\mathrm{b}}$ INRA, Unité de Biochimie \& Structure des Protéines, 78352 Jouy-en-Josas Cedex, France
}

Received 23 April 2004; accepted 27 August 2004

\begin{abstract}
Lysis of dairy starters is a prerequisite for optimum cheese maturation, since intracellular starter enzymes, particularly peptidases, can then play their role. Here we describe the different methods used to detect starter lysis in situ and current knowledge concerning the impact of lysis on cheese ripening, particularly the increase of free amino acids due to early lysis and the reduction of bitterness by hydrolysis of large hydrophobic peptides. Recent results obtained on the impact of lysis on lipolysis and amino acid catabolism are also described. Then, we present current knowledge regarding the mechanisms involved, focussing mainly on the model most investigated: Lactococcus lactis. Recent advances concerning the molecular characterization of peptidoglycan hydrolases are summarized (sequence, structure, regulation) together with current knowledge of the relationship between lysogeny and lysis. Lastly, we review the different approaches proposed to control or induce lysis in situ. In conclusion, we point out unaddressed questions. (C) 2005 Elsevier Ltd. All rights reserved.
\end{abstract}

Keywords: Lysis; Lactic acid bacteria; Cheese ripening; Peptidoglycan hydrolases

\section{Contents}

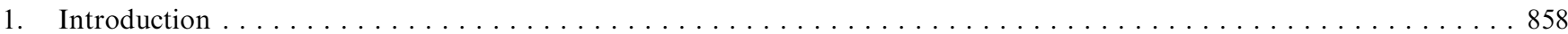

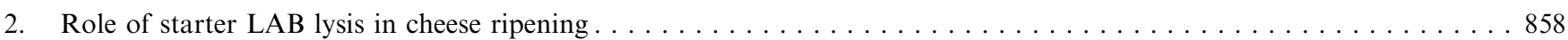

2.1. Measuring starter lysis in cheese $\ldots \ldots \ldots \ldots \ldots \ldots \ldots \ldots \ldots$

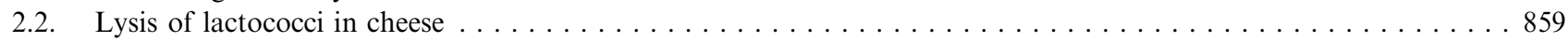

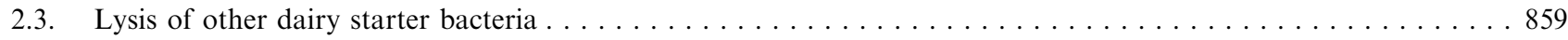

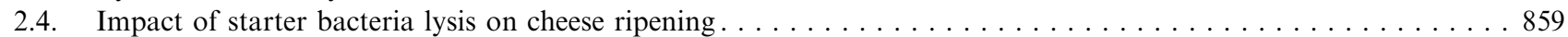

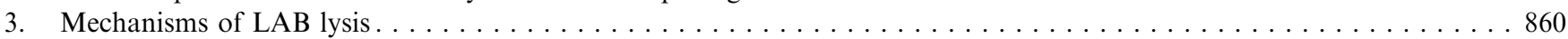

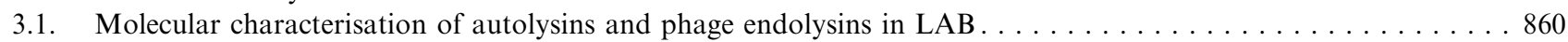

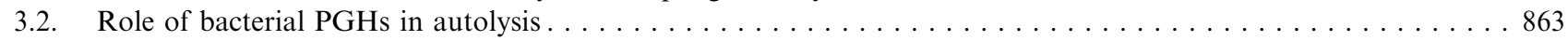

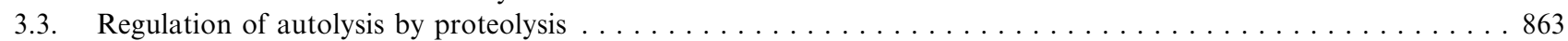

3.4. Role of prophage-encoded endolysins in bacterial lysis $\ldots \ldots \ldots \ldots \ldots$

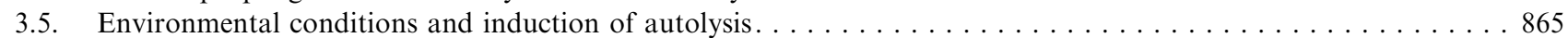

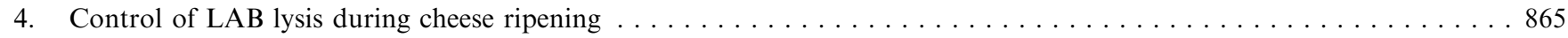

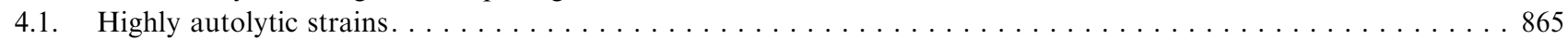

4.2. Genetically modified strains $\ldots \ldots \ldots \ldots \ldots \ldots \ldots \ldots \ldots \ldots \ldots$

4.3. Complementation of the starter with bacteriocin-producing strains $\ldots \ldots \ldots \ldots 6$

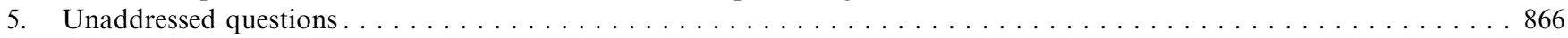

5.1. What are the physiological and environmental parameters inducing starter lysis in cheese? . . . . . . . . 866

\footnotetext{
${ }^{*}$ Corresponding author. Fax: +33223485350.

E-mail address: sylvie.lortal@rennes.inra.fr (S. Lortal).
} 
5.2. Why does the ability to lyse vary so greatly from strain to strain, regardless of the species considered? . . . . . 866

5.3. Is starter lysis a general and systematic event in all dairy products? $\ldots \ldots \ldots \ldots 7$

5.4. Apart from an increase of free amino acids and the reduction of bitterness, what is the impact of lysis in the

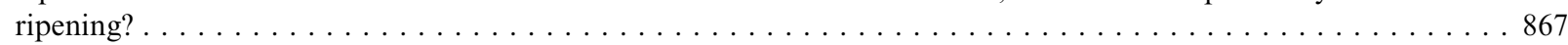

5.5. What is more suitable for ripening: permeabilized or lysed cells? In other words, is lysis really rate limiting

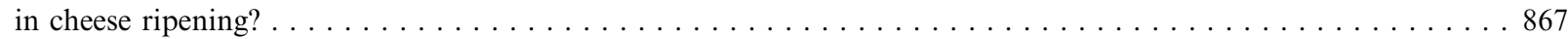

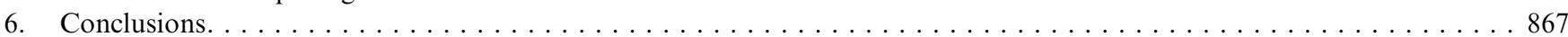

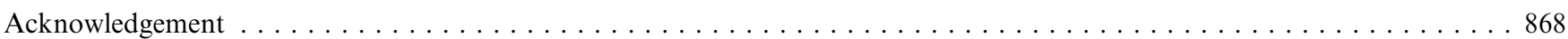

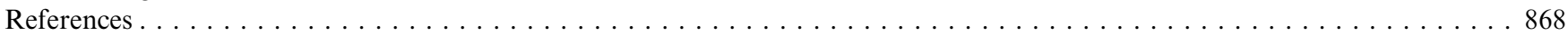

\section{Introduction}

Bacterial autolysis results from the enzymatic degradation of the cell wall peptidoglycan by endogenous peptidoglycan hydrolases (PGHs) named autolysins. Bacterial PGHs are involved in a number of different cellular functions that require modification of the rigid peptidoglycan network during growth and division (Smith, Blackman, \& Foster, 2000). Autolysis has been observed in many Gram-negative and Gram-positive bacteria (Shockman \& Höltje, 1994). It occurs generally under conditions that result in cessation of peptidoglycan synthesis, for example nutriment starvation or other unfavourable environmental conditions. Under such conditions, hydrolysis of peptidoglycan, which is essential for the cell structural integrity, may cause cellular autolysis and release of intracellular contents.

Autolysis of lactic acid bacteria (LAB) is of special interest regarding their use as starters in dairy fermentations. Controlling and increasing starter LAB lysis is considered as an essential parameter to control and accelerate cheese ripening. Indeed, LAB starters produce intracellular enzymes (peptidases, lipases and enzymes of amino acid catabolism), which play a key role in cheese flavour development during ripening. After the initial breakdown of caseins by rennet, milk endogenous proteases and bacterial cell wall protease, a set of peptidases is able to degrade the resulting peptides into free amino acids (see Kunji, Mierau, Hagting, Poolman, \& Konings, 1996, for review). Free amino acids can be subsequently catabolized to volatile aroma compounds by several enzymatic pathways (see Yvon \& Rijnen, 2001, for review). Also, esterases and lipases catalyse hydrolysis of triglycerides of milk fat in free fatty acids that are further converted to aroma compounds. They can also synthesize esters from alcohols and glycerides under certain conditions (Liu, Holland, \& Crow, 2003). The release of bacterial intracellular enzymes upon cellular lysis allows them to reach substrates present in the cheese matrix. Over the last decade, autolysis of LAB has been the subject of intensive investigation. Numerous studies aimed at measuring its impact on cheese ripening and unravelling the molecular events leading to cellular lysis in order to control it during cheese ripening. Previous reviews dedicated to this topic are those of Crow et al. (1995a), Chapot-Chartier (1996), Lortal, Lemée and Valence (1997a) and Pillidge et al. (2002).

In this review, we present the current knowledge regarding the impact of starter LAB lysis on cheese ripening, the most recent results on the molecular characterization of PGHs in several LAB as well as the various attempts to control Lactococcus lactis lysis in cheese.

\section{Role of starter LAB lysis in cheese ripening}

\subsection{Measuring starter lysis in cheese}

Although lysis of LAB in cheeses has been suspected for a very long time (Sandberg, Haglund, \& Barthel, 1930), it has been unambiguously demonstrated in situ for lactococci only in 1994: in Saint-Paulin by ChapotChartier, Deniel, Rousseau, Vassal, and Gripon (1994) and in Cheddar by Wilkinson, Guinee, O'Callaghan and Fox (1994b). Many other examples have been shown, involving varied approaches that are presented below. Due to the inclusion of bacterial cells in the cheese matrix, the demonstration of lysis in situ has to overcome some methodological problems. For this reason, several techniques are generally used in parallel to assess lysis.

Electron microscopy (EM) observations (either transmission EM or scanning EM) can reveal the presence of damaged or lysed cells at different times of ripening. This approach can be used directly on cheese sections. However, the drastic sample preparation can generate artefacts or can damage some fragile cells. Also, it can be regarded as rather subjective, as no quantification can be made. Some new approaches have been proposed more recently by using fluorescence and confocal microscopy avoiding any sample preparation (Bunthof, van Schalkwijk, Meijer, Abee, \& Hugenholtz, 2001). However, a quantitative approach in cheese is still not possible by this way.

Classical enumeration of colony forming units measures the decrease of bacterial populations based on the growth of cells on solid media, but does not adequately measure lysis. Some cells may be non-culturable yet still metabolically active, or may be dead (i.e permeabilized) but still not completely lysed as was clearly observed by confocal microscopy (Bunthof et al., 2001). 
The release of an intracellular component in cheese remains the principal method of lysis demonstration. DNA and RNA would be excellent lysis markers since they are intracellular and specific to bacteria. However, DNA and RNA are apparently rapidly degraded in cheese (Bie \& Sjöström, 1975) making any reliable quantification difficult. By contrast, several cytoplasmic enzymes, including lactate dehydrogenase (LDH), glucose phosphate dehydrogenase, fructose-1,6-biphosphate aldolase (FBP), X-prolyl-dipeptidyl-aminopeptidase (PepX), lysyl-aminopeptidase and dipeptidase, have been used successfully as lysis markers (Wilkinson, Guinee, \& Fox, 1994a; Crow et al., 1995a; Pillidge, Govindasamy-Lucey, Gopal, \& Crow, 1998; Valence, Richoux, Thierry, Palva, \& Lortal, 1998). These free enzymes in cheese are revealed by assaying for enzyme activity, by immunochemical and recently even by proteomic analysis of cheese aqueous extracts (Gagnaire et al., 2004). The immunological detection method has two advantages: (i) it is not influenced by enzyme activity variations due to enzyme instability in cheese and (ii) using specific antibodies, the lysis of one species in a complex ecosystem can be carried out. However, it must be kept in mind that the preparation of the cheese extracts to quantify the lysis markers has to be made in as mild a way as possible to avoid cell damage and/or lysis marker damage.

\subsection{Lysis of lactococci in cheese}

Law, Sharpe, and Reiter (1974) observed a decrease of starter (L. lactis subsp. cremoris NCDO924) viability in Cheddar during the ripening and a concomitant release of an intracellular dipeptidase. Since this first observation, lysis of $L$. lactis has been extensively demonstrated in Cheddar and in Saint-Paulin, where it was shown to be highly strain dependant (Chapot-Chartier et al., 1994; Wilkinson et al., 1994b; O'Donovan, Wilkinson, Guinee, \& Fox, 1996). By contrast, in cheese made from a retentate of ultrafiltrated milk, the lysis of L. lactis species was inhibited, regardless of the strain used (Saboya, Goudedranche, Maubois, Lerayer, \& Lortal, 2001; Hannon et al., 2004), indicating that the cheese matrix composition and the technology used can also influence the induction of lysis.

\subsection{Lysis of other dairy starter bacteria}

Lactobacillus helveticus lysis was demonstrated in experimental and commercial Swiss type cheeses, Emmental, Beaufort and Comté (Valence et al., 1998). In Emmental, lysis occurs early towards the end of the pressing step. It was demonstrated by immunological detection of free peptidase (PepX) as well as D-lactate dehydrogenase (both specific for $L b$. helveticus). As for lactococci, lysis was shown to have a positive impact on the proteolysis, which is in agreement with the high level of residual activity of free proteolytic enzymes in cheese juice (Gagnaire, Lortal, \& Leonil, 1998; Valence, Deutsch, Richoux, Gagnaire, \& Lortal, 2000). Lb. delbrueckii subsp. lactis was shown to lyse in swiss Gruyère (release of free PepX in cheese extracts) (Meyer \& Spahni, 1998). Regarding Streptococcus thermophilus, lysis was demonstrated in Emmental (Deutsch, Ferain, Delcour, \& Lortal, 2002); however, no data exist for yoghurts or for soft cheeses (Camembert, Reblochon), where it is frequently added with the starter to increase the initial acidification rate (Lortal, 2004).

\subsection{Impact of starter bacteria lysis on cheese ripening}

Proteolysis of caseins, conversion of free amino acids into aroma compounds and lipolysis of milk fat are all known as essential in the cheese ripening process (Fox et al., 1996). When starter lysis occurs readily, proteolysis is increased, in particular the level of free amino acids (2to 3-fold increase by the end of ripening), and bitterness is reduced, leading to a better flavour (Crow, Martley, Coolbear, \& Roundhill, 1995b; Lepeuple, Vassal, Delacroix-Buchet, Gripon, \& Chapot-Chartier, 1998b; Meijer, Dobbebbar, \& Hugenholtz, 1998). High level of starter autolysis also reduces the propensity of the PItype cell envelope proteinase in L. lactis starter strains to produce bitterness in some cheese types (Pillidge, Crow, Coolbear, \& Reid, 2003). Because of this positive impact, several authors have tried to predict the lytic behaviour of starters. Boutrou et al. (1998) used pseudocurds to test lytic ability and proteolytic activities of various industrial strains of $L$. lactis. However, the correlation between lysis and proteolysis is not easy to establish for a large number of strains.

Recent studies have addressed the question of the impact of LAB lysis on amino acid conversion to aroma compounds in cheese. In the first study, BourdatDeschamps, Le Bars, Yvon and Chapot-Chartier (2004) reported that when $\alpha$-ketoglutarate was not rate limiting, lysis of L. lactis AM2 stimulated the catabolism of aromatic amino acids and methionine, and enhanced the formation of benzaldehyde and sulphfur aroma compounds which are considered desirable aroma compounds in cheese. In a second study, Fernandez de Palenzia et al. (2004) induced starter lysis by addition of a bacteriocin-producing strain. This resulted in an increase of isoleucine (Ile) transamination and subsequent decarboxylation of the Ile-derived $\alpha$-ketoacid, leading to an increase of 2-methyl-butanal formation. Concomitantly, an enhancement of cheese aroma was detected by sensory analysis.

The relationship between the extent of lysis and the level of cheese lipolysis has been even less studied. Collins, McSweeney and Wilkinson (2003) compared two strains exhibiting similar esterasic and lipasic 
activity in vitro (as estimated on triolein and $p$ nitrophenylbutyrate substrates), and differing by their extent of lysis in cheese (estimated by LDH release in cheese juice). Levels of individual free fatty acids increased for both strains during the ripening; however, caprylic, myristic, palmitic and stearic acids were significantly higher in cheeses manufactured with the strain highly prone to lysis (L. lactis subsp. cremoris AM2), suggesting a positive link between lysis and lipolysis.

In an attempt to shorten the ripening period of Cheddar cheese, Hannon et al. (2003) added a highly autolytic strain of Lb. helveticus to the main lactococci starter. Lysis was followed by LDH release. Proteolysis was increased and a unique balanced strong flavour was obtained in the presence of this autolytic strain. This is consistent with data from various studies (reviewed by Klein \& Lortal, 1999) in which attenuated Lb. helveticus were added to increase the amount of bacterial intracellular enzymes in cheese without interfering with the acidification process.

The non-starter lactic acid bacteria (NSLAB) can reach a high biomass at the end of the ripening contributing positively, when selected and inoculated as adjunct, to the final flavour of Cheddar cheese (Crow, Curry, \& Hayes, 2001). However, even if a succession of strains is observed, the question of their in situ lysis and its impact has not been addressed until yet.

In conclusion, the rapid release of intracellular enzymes due to autolysis of LAB in the cheese matrix accelerates the ripening process, and in some cases improves the flavour. However, the impact of lysis on amino acid catabolism as well as on lipolysis has to be further explored.

\section{Mechanisms of LAB lysis}

Bacteria produce PGHs that are capable of hydrolysing bonds in their own protective cell wall peptidoglycan. In Gram-positive bacteria, peptidoglycan constitutes a strong three-dimensional network surrounding the cell. It is a polymer comprised of glycan chains (alternate of $N$-acetyl muramic acid (Mur-NAc) and of $N$-acetyl-glucosamine (Glc-NAc) residues) linked together by short peptide chains (Fig. 1). Depending on the bond they are able to cleave, PGHs have different specificities as indicated in Fig. 1. Several PGHs of identical and/or of different specificities may be present at the same time in the cell (Shockman \& Höltje, 1994; Chapot-Chartier, 1996), building a complex enzymatic system of PGHs. Since autolysins are dangerous for cell integrity, their expression and/or activity must be tightly regulated. However, under conditions where peptidoglycan synthesis is arrested, they are thought to cause cellular lysis as a result of uncontrolled activity.

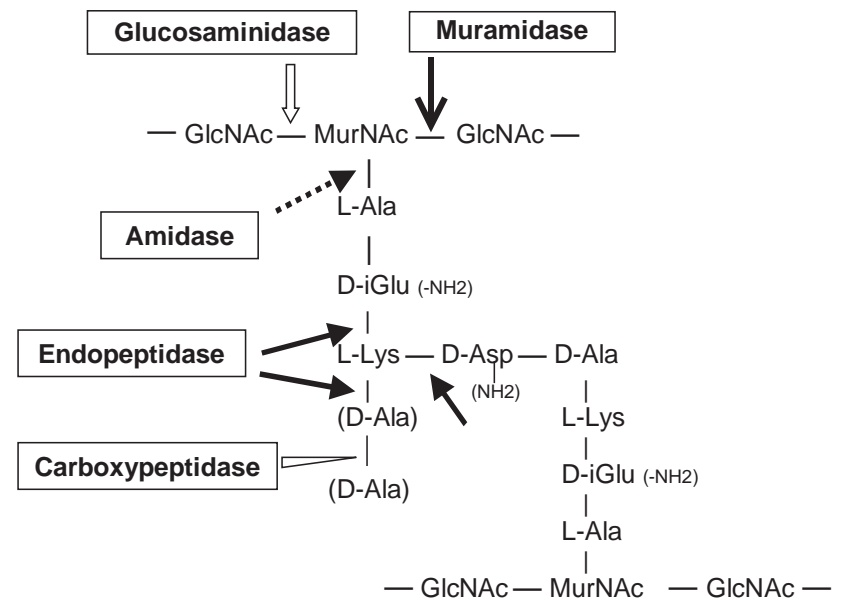

Fig. 1. Peptidoglycan structure of L. lactis and hydrolytic bond specificities of peptidoglycan hydrolases. Peptidoglycan is a heteropolymer comprised of linear chains of polysaccharides containing $N$ acetyl-muramic acid (MurNAc) and $N$-acetyl-glucosamine (GlcNAc), cross-linked by short peptidic chains. The cleavage sites of the different peptidoglycan hydrolase classes are indicated.

It is worth noting that numerous strains of $L$. lactis and other LAB species are lysogenic and carry in their genome one or several prophages encoding an endolysin with PGH activity. Prophage induction may result from a mutagenic agent (like mitomycin $\mathrm{C}$ ) or from an environmental stress (like heat shock). At the end of the phage cycle, lytic proteins are produced, the endolysin and most often a small protein, the holin, allowing the endolysin to access its substate, peptidoglycan, and causing cell lysis.

In this section, we describe the data available on LAB autolysins and prophage-encoded endolysins. Most studies concern L. lactis. However, where available, data regarding other dairy LAB species will also be presented.

\subsection{Molecular characterisation of autolysins and phage endolysins in $L A B$}

The hydrolytic specificities of PGHs present in a bacterial species can be determined by incubating a bacterial cell wall preparation under conditions allowing self-hydrolysis, and by analysing the bonds that are cleaved. For example, the increase of free reducing groups indicates the activity of a muramidase or a glucosaminidase, and the increase of free amino groups either an amidase or a peptidase (Shockman \& Höltje, 1994). Results obtained in this way for several LAB species are summarized in Table 1.

Renaturing SDS-PAGE (zymogram) is an efficient technique to detect peptidoglycan hydrolase activity. Various substrates can be included in the polyacrylamide gel: whole cells, cell walls or purified peptidoglycan of the species under study or of 
Table 1

Enzymatic activities detected in vitro following cell wall self-hydrolysis and main peptidoglycan hydrolases detected by renaturing SDS-PAGE in different lactic acid bacteria species

\begin{tabular}{|c|c|c|c|c|c|}
\hline \multirow[t]{2}{*}{ Bacterial species } & \multirow{2}{*}{$\begin{array}{l}\text { Enzymatic activities } \\
\text { detected in vitro }\end{array}$} & \multicolumn{3}{|c|}{ Renaturing electrophoresis } & \multirow[t]{2}{*}{ References } \\
\hline & & Substrate & $\begin{array}{l}\text { Number of } \\
\text { major bands }\end{array}$ & $\begin{array}{l}\text { Apparent } \\
\text { mass } M_{\mathrm{r}} \\
(\mathrm{kDa})\end{array}$ & \\
\hline \multirow[t]{2}{*}{ Lactococcus lactis } & $\begin{array}{l}N \text {-acetyl-muramidase } \\
\text { Glycosidase and } \\
\text { [amidase or } \\
\text { endopeptidase] }\end{array}$ & $\begin{array}{l}\text { M. lysodeikticus } \\
\text { L. lactis }\end{array}$ & 2 & $18 / 45$ & Buist et al. (1995a) \\
\hline & & & 1 or 2 & 45 or $45 / 46^{\mathrm{a}}$ & $\begin{array}{l}\text { Østlie et al. (1995) } \\
\text { Riepe et al. (1997) } \\
\text { Lepeuple et al. (1998a) } \\
\text { Mou, Sullivant, \& Jago } \\
\text { (1976) }\end{array}$ \\
\hline Streptococcus thermophilus & $\mathrm{ND}^{\mathrm{b}}$ & $\begin{array}{l}\text { M. lysodeikticus } \\
\text { S. thermophilus }\end{array}$ & $\begin{array}{l}0 \\
1 \text { or } 2\end{array}$ & 51 or $31^{\mathrm{a}} / 51$ & $\begin{array}{l}\text { Husson-Kao et al. } \\
(2000 \mathrm{a}, \mathrm{b})\end{array}$ \\
\hline Lactobacillus helveticus & $N$-acetyl-muramidase & $\begin{array}{l}\text { M. lysodeikticus } \\
\text { Lb. helveticus } \\
\text { Cells } \\
\text { SDS cell walls }\end{array}$ & $\begin{array}{l}4 \\
2 \\
3\end{array}$ & $\begin{array}{l}30 / 42 \\
30 / 42 \\
30 / 37 / 42\end{array}$ & $\begin{array}{l}\text { Lortal et al. (1997a) } \\
\text { Valence \& Lortal (1995) }\end{array}$ \\
\hline $\begin{array}{l}\text { Lactobacillus delbrueckii } \\
\text { subsp. lactis }\end{array}$ & ND & M. lysodeikticus & 2 & $31 / 44$ & Lortal et al. (1997b) \\
\hline Lactobacillus acidophilus & $N$-acetyl-muramidase & M. lysodeikticus & 4 & $27 / 28 / 30 / 41$ & Lortal et al. (1997b) \\
\hline Leuconostoc citreum & $\begin{array}{l}\text { Glycosidase and } \\
\text { [amidase or } \\
\text { endopeptidase] }\end{array}$ & M. lysodeikticus & 2 & $41 / 52$ & $\begin{array}{l}\text { Cibik \& Chapot-Chartier } \\
\text { (2000) }\end{array}$ \\
\hline $\begin{array}{l}\text { Lactobacillus casei subsp. } \\
\text { casei }\end{array}$ & Glycosidase & Lb. casei & 2 & $49 / 55$ & Cappa \& Bottazzi (1996) \\
\hline
\end{tabular}

${ }^{\text {a } E n d o l y s i n ~ e n c o d e d ~ b y ~ a ~ p r o p h a g e, ~ d e t e c t e d ~ o n l y ~ i n ~ s o m e ~ s t r a i n s . ~}$

${ }^{\mathrm{b}} \mathrm{ND}$ : not determined.

Micrococcus lysodeikticus, a classical PGH substrate. PGH activity is revealed by the presence upon incubation of a translucent band in an opaque background, and the apparent molecular mass of the PGH can be estimated (Fig. 2). This method was used successfully in several LAB species as summarized in Table 1 . In general, several lytic bands are detected and the profile is rather stable within a species with characteristic major bands conserved between strains (Østlie, Vegarud, \& Langsrud, 1995; Lortal, Valence, Bizet, \& Maubois, 1997b; Cibik \& Chapot-Chartier, 2004). It is worth noting that this technique allows detection only of enzymes able to renature after SDS-PAGE and that heteromultimeric enzymes cannot be detected.

Several genes encoding PGHs have been identified in LAB (Table 2). The gene encoding the major autolysin AcmA of L. lactis MG1363 was the first to be cloned and sequenced (Buist et al., 1995a). It encodes a protein of $46.5 \mathrm{kDa}$, endowed with an N-terminal putative signal peptide, for exportation across the cytoplasmic membrane. AcmA has a modular structure with two domains: a catalytic domain (identified from sequence homology to the $\mathrm{N}$-acetyl-muramidase Mur2 of

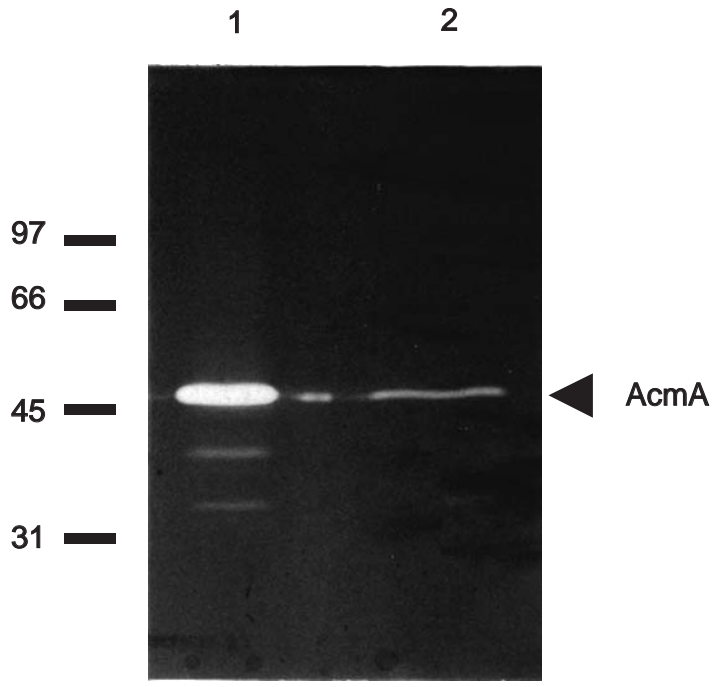

Fig. 2. Detection of peptidoglycan hydrolases in L. lactis NCDO763 by renaturing SDS-PAGE with a gel containing $0.2 \%$ autoclaved $M$. lysodeikticus cells. Lane 1: cell extract; lane 2: culture supernatant. AcmA is the major autolysin; the weaker bands detected in cell extract could correspond to proteolytic degradation products of AcmA as in L. lactis MG1363 (Buist et al., 1995a), or to minor autolysin or endolysin activities. 
Table 2

Peptidoglycan hydrolases from lactic acid bacteria characterized at the molecular DNA level

\begin{tabular}{|c|c|c|c|c|c|}
\hline $\begin{array}{l}\text { Bacterial species Enzyme } \\
\text { name }\end{array}$ & $\begin{array}{l}\mathrm{MM} \\
(\mathrm{kDa})\end{array}$ & PI calculated & Hydrolytic specificity ${ }^{a}$ & Structure & References \\
\hline
\end{tabular}

Lactococcus lactis (strain MG1363 and/or IL1403)

AcmA

46.5

10.8

5.0

$\mathrm{AcmB}$

$\mathrm{AcmC}$

23.7

10.2

4.3

(ND)

AcmD

37.5

$\mathrm{N}$-acetyl-muramidase

or $\mathrm{N}$-acetyl-

glucosaminidase

YjgB

20.7

5.8

(ND)

Endopeptidase

Streptococcus

thermophilus (strain

CNRZ302)

Mur1

Leuconostoc citreum

(strain 22R)

Mur
23.8
24.7

9.7

(ND)

$N$-acetyl-muramidase or $\mathrm{N}$-acetyl-

glucosaminidase

(ND)

$\mathrm{N}$-acetyl-muramidase

or $N$-acetyl-

glucosaminidase
Putative signal sequence, two domains

N-terminal: catalytic domain ${ }^{b}$ C-terminal:peptidoglycan

binding domain

Three sequence repeats LysM

(44 AA)

Putative signal sequence, three domains

$\mathrm{N}$-terminal: domain rich in $\mathrm{S}$

$\mathrm{T} / \mathrm{G} / \mathrm{P}$

Central region: catalytic

domain $^{\mathrm{b}}$

C-terminal: domain with putative $\mathrm{Zn}$ binding site

Putative signal sequence, one domain

Catalytic domain.

Putative signal sequence, two domains

N-terminal: catalytic domain ${ }^{b}$

$\mathrm{C}$-terminal: three sequence

repeats LysM (44 AA)

Putative signal sequence, one

domain

Catalytic domain $^{\mathrm{c}}$

Putative signal sequence, one domain

Catalytic domain ${ }^{\mathrm{b}}$

Putative signal sequence, one domain

Catalytic domain ${ }^{\mathrm{b}}$
Husson-Kao et al. (2000b)

Buist et al. (1995a)

Steen et al. (2001)

Steen et al. (2003)

Huard et al. (2003)

Huard et al. (2004)

Huard et al. (2004)

Huard et al. (2004)

Cibik et al. (2001)

\footnotetext{
${ }^{a}$ Determined experimentally, or according to sequence similarity (ND).

${ }^{\mathrm{b}}$ Sequence similarity with the catalytic domain of Enterococcus hirae $N$-acetyl-muramidase Mur2.

${ }^{\mathrm{c}}$ Sequence similarity with the catalytic domain of Bacillus sphaericus DL-endopeptidase II.
}

Enterococcus hirae) and a cell wall binding domain composed of three amino acid sequence repeats (named LysM domains) (Steen et al., 2003). AcmA was shown to correspond to the main activity band detected by zymogram in L. lactis MG1363, whereas the minor lower bands in zymogram were shown to be degradation products since they were absent in an acm $A$ minus derivative (Buist et al., 1995a).

Four other putative PGHs have been identified by amino acid sequence similarity searching of the whole genome sequence of L. lactis IL1403 (Bolotin et al., 2001): AcmB, AcmC, AcmD and YjgB. They were shown to hydrolyse peptidoglycan and their genes are transcribed in L. lactis MG1363 during growth in M17 medium (Huard et al., 2003; Huard et al., 2004). AcmB, $\mathrm{AcmC}$ and AcmD possess, like AcmA, a catalytic domain homologous to the one of $E$. hirae muramidase Mur-2. The hydrolytic specificity of three of them (AcmA, B and C) was determined on purified Bacillus subtilis peptidoglycan substrate by analysis of the 
released muropeptides by HPLC and mass spectrometry (Steen et al., 2001; Huard et al., 2003, 2004). These studies indicated that the three enzymes have $N$-acetylglucosaminidase activity rather than $N$-acetyl-muramidase activity predicted by sequence similarity. In conclusion, L. lactis contains at least three glucosaminidases with different structure, one putative endopeptidase (YjgB), one putative muramidase (AcmD), whereas no amidase is present. Regarding the number of enzymes, the $L$. lactis $\mathrm{PGH}$ complement of five enzymes appears of low complexity compared to those of B. subtilis and Escherichia coli, which contain 35 and 18 PGHs respectively (Smith et al., 2000; Höltje, 1995).

In other LAB species, only two PGHs have been cloned and sequenced: (i) one in $S$. thermophilus exhibiting sequence similarity with the catalytic domain of AcmA but without specific cell wall binding domain (Husson-Kao, Mengaud, Benbadis, \& Chapot-Chartier, 2000a) and (ii) its homolog in Leuconostoc citreum (Cibik, Taillez, Langella, \& Chapot-Chartier, 2001).

In certain LAB lysogenic strains, endolysin activity was detected in cellular extracts, without any prophage inducing factor, suggesting a base level of constitutive expression. This was observed in L. lactis subsp. cremoris AM2, which is highly prone to lyse in cheese and where the $46-\mathrm{kDa}$ activity detected by zymogram analysis corresponds to the endolysin of the temperate bacteriophage carried by the strain (Lepeuple, van Gemert, \& Chapot-Chartier, 1998a). This is also true for strains of $S$. thermophilus where the major activity at $31 \mathrm{kDa}$ in zymogram of bacterial cellular extracts corresponds to the endolysin of the resident temperate phage (Husson-Kao et al., 2000b). Several endolysins have been characterized at the molecular level in temperate phages of L. lactis and lactobacilli (Gasson, 1996; Table 3).

\subsection{Role of bacterial PGHs in autolysis}

The role of AcmA during growth and lysis was studied by constructing an acm $A$ deletion mutant in $L$. lactis MG1363 (Buist et al., 1995a). This mutant formed long chains during growth in semi-synthetic medium, indicating that $\mathrm{AcmA}$ is involved in the separation of cells after division. This physiological role has been already described for many autolysins (Shockman \& Höltje, 1994; Smith et al., 2000). The acmA mutant exhibited reduced autolysis during a prolonged incubation after maximal growth in synthetic medium.

However, the involvement of AcmA in lysis observed in cheese has not been clearly established especially when early and extensive lysis is observed. Indeed, strain L. lactis subsp. cremoris 2250 lyses readily and early in Cheddar cheese but acmA knockout in that strain did not change its lysis kinetics (Pillidge et al., 1998). In addition, detection of AcmA using an antiserum to
AcmA in several commercial strains indicated differences in levels of AcmA expression that did not correlate with levels of autolysis of the strains grown in milk (Pillidge et al., 2002). All these results suggest that other genes and/or other factors must therefore be implicated in the particular ability of some strains to lyse in cheese.

AcmB of L. lactis has been shown to contribute to autolysis in buffered solutions (Huard et al., 2003), but no cheese experiment was carried out with the corresponding mutant. The physiological role as well as the contribution in lysis of the other PGHs of L. lactis and other dairy LAB is still not known.

\subsection{Regulation of autolysis by proteolysis}

The regulation of PGH activity by proteases has been described in several bacteria (Shockman \& Höltje, 1994). L. lactis produces a cell-wall-associated protease (PrtP also called lactocepin), hydrolysing caseins during growth in milk. PrtP was shown to hydrolyse the major autolysin AcmA. The autolysis of L. lactis MG1363 in synthetic broth varies in relation to the presence of this protease and its specificity (Buist, Venema, \& Kok, 1998). When the strain MG1363 expressed PI-type protease, its autolysis was strongly reduced compared to the same strain exhibiting PIII-type protease or hybrid PI-PIII protease. However, this result was not confirmed when industrial strains were grown in milk. In this case, lysis was not clearly correlated to the PrtP type and to the degradation of AcmA (Govindasamy-Lucey, Gopal, Sullivan, \& Pillidge, 2000). Thus, autolysis of industrial strains after maximal growth in milk appears as a complex multifactorial event. Another extracellular protease, HtrA, was characterized in L. lactis IL1403 (a plasmid-free strain devoid of PrtP) that can also contribute to the degradation of the mature form of AcmA (Poquet et al., 2000). Degradation of autolysins or even phage-encoded lysins by cell proteases may contribute to some of the lower bands seen on zymograms.

\subsection{Role of prophage-encoded endolysins in bacterial lysis}

Early studies correlated the thermolytic response observed in several L. lactis subsp. cremoris strains to the presence of a thermoinducible prophage (Feirtag \& McKay, 1987; Wiederholt \& Steele, 1993). More recently, the autolytic phenotype of certain LAB strains was also associated to their lysogenic state. A prophagecured derivative of the fast-lysing strain L. lactis subsp. cremoris AM2 was shown to lyse very slowly and to a limited extent in cheese experiments (Lepeuple et al., 1998b). Similarly, the lytic phenotype of several strains of $S$. thermophilus observed through carbon starvation at the end of growth has also been associated to the 
Table 3

Main endolysins characterised in temperate bacteriophages of L. lactis, S. thermophilus and different lactobacilli

\begin{tabular}{llll}
\hline Bacterial species phage name & $\begin{array}{l}\text { Hydrolytic } \\
\text { specificity }\end{array}$ & Structure (two domains) & References \\
\hline
\end{tabular}

Lactococcus lactis

$\mathrm{R} 1 \mathrm{t}$

Amidase

Tuc2009

$\Phi \mathrm{LC} 3$

$\Phi$ AM2

BK5-T

$\Phi 31$

bIL285, bI1286, bIL309

Streptococcus thermophilus Ф01205

Sfi11, Sfi21, Sfi18, Sfi19

Lactobacillus delbruekii subsp.

bulgaricus

mv1

Muramidase

$\mathrm{mv} 4$

Lactobacillus helveticus

$\Phi$-0303

Muramidase

Lactobacillus gasseri

$\Phi$ adh

Muramidase

Lactobacillus plantarum

Фgle

Muramidase

Lactobacillus johnsonii

Lj965

Lj928

Muramidase

Lactobacillus casei

$\Phi$ A2

Muramidase

Amidase

Amidase
N-terminal: homologous to catalytic domain of
endolysins of phage DP-1 and BK5-T of L. lactis

C-terminal: homologous to zoocin A of Streptococcus zooepidemicus

N-terminal: homologous to catalytic domain of endolysins of phages $\mathrm{Cp}-1, \mathrm{Cp}-7$ and $\mathrm{Cp}-9$ of $S$. pneumoniae

C-terminal: no sequence homology

N-terminal: homologous to catalytic domain of endolysins of phage Cp-1, Cp-7 and Cp-9 of $S$. pneumoniae

C-terminal: no sequence homology.

N-terminal: homologous to catalytic domain of endolysins of phage Cp-1, Cp-7 and Cp-9 of $S$. pneumoniae

C-terminal:sequence homology with C-terminal domain of phage endolysins of $L b$. johnsonii and $L b$ plantarum

N-terminal: homologous to catalytic domain of endolysins of phage Cp-1, Cp-7 and Cp-9 of $S$. pneumoniae

C-terminal: no sequence homology.

N-terminal: homologous to catalytic domain of endolysins of phage $\mathrm{Cp}-1, \mathrm{Cp}-7$ and $\mathrm{Cp}-9$ of $S$. pneumoniae

C-terminal: sequence homology with C-terminal domain of phage endolysins of $L b$. gasseri and Lb. Plantarum

N-terminal: homologous to $S$. pneumoniae LytA and endolysin of L. lactis phage $\mathrm{rlt}$

C-terminal: sequence homology with C-ter- of enterolysin of $E$. faecalis van Sinderen et al., 1996

Arendt, Daly, Fitzgerald, \& van de Guchte, 1994

Birkeland (1994)

Lepeuple et al. (1998a)

Boyce, Davidson, \& Hillier (1995)

Madsen, Mills, Djordjevic, Israelsen, \& Klaenhammer (2001)

Chopin, Bolotin, Sorokin, Ehrlich, \& Chopin (2001)

Sheehan, Stanley, Fitzgerald, \& van Sinderen (1999) Lucchini, Desiere, \& Brüssow (1999)

Boizet, Lahbib-Mansais, Dupont, Rizenthaler, \& Mata (1990)

Deutsch, Guezenec, Piot, Foster, \& Lortal (2004)

Heinrich, Binisshofer, \& Bläsi (1995)

Kakikawa et al. (2002)

Desiere, Pridmore, \& Brüssow (2000)

Moscovo \& Suarez (2000)

\footnotetext{
${ }^{\mathrm{a} A c c o r d i n g}$ to sequence similarity.
} 
presence of a prophage. One hypothesis is that lysis proteins are expressed at a basal non-lethal level, their activity being enhanced by certain environmental conditions like lactose starvation or $\mathrm{NaCl}$ addition (Husson-Kao, Mengaud, Gripon, Benbadis, \& ChapotChartier, 1999). The lytic behaviour of the lysogenic strains of $S$. thermophilus was not tested in cheese.

So in a limited number of LAB strains, a link can be established between the presence of a prophage and fast autolysis. However, although a study based on PCR screening of $L$. lactis strains with primers for conserved integrase gene suggested that this observation could be extended to a higher number of strains (O'Sullivan, Ross, Fitzgerald, \& Coffey, 2001), it is likely that a high number of exceptions can be encountered. Indeed, numerous LAB strains contain active or remnant prophages, which does not imply automatically that all of them will be highly autolytic. For example, Pillidge et al. (2002) reported that both autolytic and non-autolytic strains such as 2250 and HP contain the same prophage. Similarly, by PCR screening with primers specific for the endolysin found in L. lactis AM2, no correlation could be found between the presence of the lysin gene and high ability to lyse (M.-P. Chapot-Chartier, unpublished data). Similarly, in $L b$. helveticus, no relationship between lysis and lysogeny was observed in the case of the lysogenic strain CNRZ 303. A prophage-cured derivative of this strain lysed in cheese and also in vitro to the same extent as the mother strain (Deutsch, Neveu, Guezenec, Ritzenhaler, \& Lortal, 2003).

\subsection{Environmental conditions and induction of autolysis}

The effect of culture medium composition and temperature on L. lactis autolysis was reported by Vegarud, Castberg and Langsrud (1983). Especially when lactose was replaced by glucose as the carbon source, growth and autolysis rates were increased. Many strains of LAB lyse after maximal growth. Some of them lyse readily as soon as the medium is depleted of a carbon source, as described for some L. lactis strains (Riepe, Pillidge, Gopal, \& McKay, 1997) and S. thermophilus strains (Husson-Kao et al., 1999). Lysis of $S$. thermophilus lysogenic strains with autolytic phenotype could also be induced by other environmental factors like $\mathrm{NaCl}$ concentration, presence of low level of ethanol in the medium or heat shock. Also, as already cited above, lysis of thermolytic L. lactis strains can be induced by a temperature shift from 38 to $40{ }^{\circ} \mathrm{C}$ mimicking Cheddar cheese manufacturing conditions (Feirtag \& McKay, 1987; Wiederholt \& Steele, 1993; Wilkinson, Guinee, O' Callaghan, \& Fox, 1995). These observations suggest that it is possible to induce lysis by changing environmental conditions in a way, which would be compatible with the technology applied. For example, lysis of lysogenic L. lactis subsp. cremoris
SK110 was obtained by a temperature shock applied during cheese manufacturing, which resulted in increased rate of amino acid production (Meijer et al., 1998).

\section{Control of LAB lysis during cheese ripening}

Several methods have been proposed to control lysis of L. lactis starters in cheese: to select natural highly autolytic strains, to construct genetically modified (GM) strains with inducible lysis and to provoke lysis "from the outside" by adding an additional strain producing a bacteriocin in the starter.

\subsection{Highly autolytic strains}

Various screening assays have been proposed to detect highly autolytic strains: quantification of lysis in buffers, or media mimicking cheese conditions or in milk (Lortal et al., 1997a; Boutrou et al., 1998; Pillidge et al., 1998) or studying the link between lysogeny and lysis (O'Sullivan et al., 2001). However, so far, it is not possible from these results to unequivocally predict for a strain its extent of lysis in cheese.

\subsection{Genetically modified strains}

GM strains of $L$. lactis with increased or inducible lysis have been constructed. The strategy consisted of placing a gene (encoding the major AcmA autolysin or a phage endolysin) under the control of an inducible promoter. Various such promoters have been isolated, inducible by $\mathrm{NaCl}$, heat or cold shock, acid $\mathrm{pH}$ or nisin (reviewed by Sanders, Venema, \& Kok, 1999). So far, the latter was tested and shown to be efficient in cheese (de Ruyter, Kuipers, Meijer, \& de Vos, 1997). However, the extent of in situ lysis was only four times higher than the mother strain (as measured by LDH release) which was not more than the natural variation between strains. Two patents exist on this approach (Gasson, 1994; Buist, Venema, Kok, \& Ledeboer, 1995b). Recently, an inducible lysis system was constructed with the nisininducible promoter controlling the expression of enterolysin A, a metalloendopeptidase produced by Enterococcus faecalis. This system exhibits high efficiency to lyse L. lactis strains since a 27 -fold increase of LDH activity release in model cheese was reported upon overexpression of enterolysin A. No biochemical analysis of cheese was reported (Hickey, Ross, \& Hill, 2004). Leaky L. lactis strains were also constructed by Walker and Klaenhammer (2001) based on the controlled expression of lysin-holin cassettes contained in prophage that were naturally present in the strains. These strains can release $\beta$-galactosidase used as a reporter enzyme, during growth without lysis; however, the five 
L. lactis peptidases and the two Lb. helveticus peptidases tested were not externalized (Tuler, Callanan, \& Klaenhammer, 2002). The strains were not tested in a cheese assay.

As the addition of GM starters is not allowed in all countries, this approach is limited by legal barriers. There is also a lack of widespread consumer acceptance. Moreover, in our opinion, because construction of GM starters requires complex molecular techniques, only a limited number of strains can be manipulated, restricting the pool of strains able to be used in cheese making whereas in nature many strains with a wide range of autolytic properties are available.

\subsection{Complementation of the starter with bacteriocin- producing strains}

The bacteriolytic effect of some bacteriocins has been well documented. Another way to increase in situ lactococcal lysis has been proposed by adding a strain producing a bacteriocin to the main starter (Morgan, Ross, \& Hill, 1997; Martinez-Cuesta, Pelaez, Juraez, \& Requena, 1997). A strain of $L$. lactis producing the bacteriocins lactococcins $\mathrm{A}, \mathrm{B}$ and $\mathrm{M}$ used together with the non-lytic strain L. lactis HP sensitive to these bacteriocins allowed a significant increase of its lysis. The control of this new lytic system was improved by using a three-strain starter: one acidifying strain insensitive to the bacteriocins, one sensitive "sacrificial" strain and one producing the bacteriocin (Morgan, O'Sullivan, Ross, \& Hill, 2002). Sensory analysis of the experimental cheeses revealed a significant decrease of bitterness and improvement of cheese flavour. Recently, it was shown that in a mixed starter, a lacticin 3147producing strain enhanced lysis of two other strains chosen for their sensitivity to the bacteriocin and for their complementary action on Ile catabolism. As a result, an increase of Ile transamination was observed as well as an increase of the volatile derivative 2methylbutanal. In addition, cheese flavour was enhanced (Martinez-Cuesta, Pelaez, Juraez, \& Requena, 2002; Fernandez de Palenzia et al., 2004). A strain producing another bacteriocin, lacticin 481 , was used to lyse a non-autolytic starter. This latter bacteriocin presented the advantage to induce the release of intracellular enzymes without complete inhibition of growth thus preserving the acid-producing capability of the starter (O'Sullivan, Morgan, Ross, \& Hill, 2002). Also, the use of a nisin-producing $L$. lactis starter to improve autolysis of an adjunct $L b$. delbruekii subsp. bulgaricus strain, with concomitant enhanced proteolysis to improve Cheddar cheese ripening was recently described (Sallami, Kheadr, Fliss, \& Vuillemard, 2004).

However, in a complex ecosystem, the presence of a bacteriocin-producing strain can have an effect on the growth of secondary flora depending on its activity spectrum (O'Sullivan, Ross, \& Hill, 2003). Moreover, this approach leads to an increase in costs (additional starter). In terms of the mechanism of lysis, endogenous autolysin activity in the target strain is still necessary for bacteriocin-induced lysis to occur (Martinez-Cuesta et al., 2000).

\section{Unaddressed questions}

Lysis is a complex enzymatic process, resulting from the activity of a mixture of lytic enzymes (autolysins, phage endolysins) on a complex dynamic substrate, the peptidoglycan in the cell wall. In our opinion, several fundamental questions have still to be answered to have a complete view of all the mechanisms involved and to control the lysis in cheese, and of course to manage its impact on cheese ripening.

\subsection{What are the physiological and environmental parameters inducing starter lysis in cheese?}

In other words, which environmental conditions or which stress linked to the manufacturing process (carbon starvation, bacteriocin production, cooking, salting, etc.) is really inducing lysis in cheese? To answer this question, the molecular as well as biochemical regulations of autolysins and endolysins expression have to be studied. The increasing number of available wholegenome sequences and dedicated transcriptome and proteome analyses will help to address this point.

\subsection{Why does the ability to lyse vary so greatly from strain to strain, regardless of the species considered?}

In vitro as well as in many cheeses, the ability to lyse was shown to be highly strain dependent. Understanding this would allow to build highly reliable tests to predict efficiently the lysis of a starter. Several hypotheses exist: (i) a more efficient lytic system (autolysins less tightly regulated, basal and sublethal levels of endolysin and holin expression, etc.); (ii) differences in cell wall composition [indeed, the variations of the amount of teichoic acids, the extent of peptidoglycan reticulation at the interpeptidic bridge or its acetylation are well known to modulate lysis in model species. The cell wall composition of LAB was recently reviewed (Delcour, Ferain, Deghorain, Palumbo, \& Hols, 1999) but the strain to strain variation was rarely investigated (Gopal \& Crow, 1993)] and (iii) the presence of one or several prophages, possibly defective, in the genome, their expression inducing a more or less extended lysis.

These hypotheses do not exclude each other, which is opening a large field of investigations. 
5.3. Is starter lysis a general and systematic event in all dairy products?

We do not have an exhaustive view of lysis in the different types of cheese or dairy products. Most studies have been done in experimental hard cheeses, and mainly with $L$. lactis and Lb. helveticus. Concerning secondary flora, some data concerning Propionibacterium freudenreichii are available (Lemee, Lortal, Cesselin, $\&$ van Heijenoort, 1994). Their lysis was shown to be tardy and limited in Emmental (Valence et al., 1998); however, only one strain was tested. As far as we know, no data exist in the literature regarding lysis of surface flora such as corynebacteria, yeast or moulds used to manufacture soft-type cheeses. Taking into consideration the extreme population density in the surface of those types of cheeses, knowledge regarding even partial lysis depending on the ripening conditions would help to control the final cheese quality. Lastly, it is not known whether lysis of one bacterial species can induce, or delay, lysis of another one in the complex cheese ecosystems.

\subsection{Apart from an increase of free amino acids and the reduction of bitterness, what is the impact of lysis in the ripening?}

Increasing the amount of free amino acids is not sufficient to accelerate ripening, especially in terms of flavour development. Indeed the subsequent step, amino acid catabolism, as well as free fatty acid metabolism probably become the rate-limiting steps of aroma compound formation. In the case of L. lactis starter in semi-hard model cheese, transamination, the first step of amino acid conversion to aroma compounds, is the limiting step (Yvon \& Rijnen, 2001). This limitation can be removed by addition of $\alpha$-ketoglutarate (Yvon, Berthelot, \& Gripon, 1998). Then, as reported above, recent studies indicate that, when $\alpha$-ketoglutarate is not in limiting concentration, starter L. lactis lysis stimulates amino acid transamination (Bourdat-Deschamps et al., 2004; Fernandez de Palenzia et al., 2004). $\alpha$-Ketoacids are not aromatic compounds and they have to be degraded further to produce volatile aroma compounds. Their chemical oxidation leading to aldehydes (with two carbon atoms less than amino acid) as well as their enzymatic decarboxylation leading to aldehydes (with one atom less than amino acid) appears also to be favoured by cell lysis. However, the impact of starter lysis on the activity and stability of the other enzymes involved in aroma formation such as $\alpha$-ketoacid, alcohol and aldehyde dehydrogenases, especially those dependent on cofactors, requires further evaluation.

Moreover, lysis does not release only enzymes but also other intracellular components such as nucleic acids, vitamins, minerals, etc. All these molecules could play a role, either directly or indirectly by stimulating the growth of other flora. Lastly, the role of lysis in texture development has not been studied. One of the practical limitations to fully elucidate the impact of lysis is the difficulty to generate easily various extents of lysis of the same strain in the same cheese matrix.

\subsection{What is more suitable for ripening: permeabilized or lysed cells? In other words, is lysis really rate limiting in cheese ripening?}

Since certain enzymes are likely to be more active inside the cells (because they require cofactors such as NADH), it seems likely that an extensive early lysis may not be the absolute goal and that a balance of lysed and intact cells is necessary to obtain good quality cheese (Crow et al., 1995a). From several studies, it appears that before lysis (resulting from cell envelope disruption), cells are first permeabilized (Niven \& Mulholland, 1998; Bunthof et al., 2001) and stabilized to some extent in the cheese environment (Chapot-Chartier et al., 1994). Cell membrane permeabilization could facilitate the access of the substrates to intracellular enzymes. For instance, a previous study has shown that bacteriocininduced cell permeabilization increased branched-chain amino acid catabolism (Martinez-Cuesta et al., 2002). It would be of interest to investigate the respective contribution of cell lysis and permeabilization to the acceleration of amino acid catabolism, as well as the products formed since enzyme stability and cofactor availability are likely to be different. We can hypothesize that a well-balanced repartition between permeabilized and lysed cells, or a succession in time of permeabilized state followed by lysis will be more efficient for optimized contribution of bacterial enzymes during ripening.

\section{Conclusions}

During the last decade, studies of bacterial lysis in internally bacteria-ripened cheese have shown that the major positive effect is a decrease of bitterness resulting from the hydrolysis of casein-derived hydrophobic peptides by released intracellular bacterial peptidases. Also, these studies pointed out that the ability to lyse is highly strain dependant. A great level of knowledge was gained on peptidoglycan hydrolases present in L. lactis. As far as mechanisms are concerned, and from the results gained in L. lactis, the lysogenic state seems to generate a better ability to lyse. This is apparently not true in other LAB, such as thermophilic lactobacilli. Based on the gained knowledge, several approaches have been proposed to control and induce bacterial lysis during ripening. GM strains with efficient inducible lysis systems have been constructed but their use is still 
limited by legal barriers. Strain diversity among a species can be exploited to select highly autolytic strains. Another interesting approach is the use of bacteriocinproducing strains to lyse starter strains.

The main future challenges are (i) to understand the molecular basis of the strain dependency of the ability to lyse and (ii) to explore the link between the physiological state of the cells (viable, non-viable), the cell envelope integrity (permeabilized, lysed cells) and the in situ enzymatic reactions in cheese especially those involved in aroma compounds formation.

\section{Acknowledgement}

We are indebted to John Hannon for improving the English version and for fruitful discussions.

\section{References}

Arendt, E. K., Daly, C., Fitzgerald, G. F., \& van de Guchte, M. (1994). Molecular characterization of lactococcal bacteriophage Tuc2009 and identification and analysis of genes encoding lysin, a putative holin and two structural proteins. Applied and Environmental Microbiology, 60, 1875-1883.

Bie, R., \& Sjöström, G. (1975). Autolytic properties of some lactic acid bacteria used in cheese production. Part I: material and methods. Milchwissenschaft, 30, 653-657.

Birkeland, N.-K. (1994). Cloning, molecular characterization and expression of the genes encoding the lytic functions of lactococcal bacteriophage FLC3: a dual lysis system of modular design. Canadian Journal of Microbiology, 40, 658-666.

Boizet, B., Lahbib-Mansais, Y., Dupont, L., Rizenthaler, P., \& Mata M. (1990). Cloning, expression and sequence analysis of an endolysin-encoding gene of Lactobacillus bulgaricus bacteriophage mv1. Gene, 94, 61-67.

Bolotin, A., Wincker, P., Mauger, S., Jaillon, O., Malarme, K., Weissenbach, J., Ehrlich, S. D., \& Sorokin, A. (2001). The complete genome sequence of the lactic acid bacterium Lactococcus lactis ssp. lactis IL1403. Genome Research, 11, 731-753.

Bourdat-Deschamps, M., Le Bars, D., Yvon, M., \& Chapot-Chartier, M. P. (2004). Autolysis of Lactococcus lactis AM2 stimulates the formation of certain aroma compounds from amino acids in a cheese model. International Dairy Journal, 14, 791-800.

Boutrou, R., Sepulchre, A., Pitel, G., Durier, C., Vassal, L., Gripon, J. C., \& Monnet, V. (1998). Lactococcal lysis and curd proteolysis: two predictable events important for the development of cheese flavour. International Dairy Journal, 8, 609-616.

Boyce, J. D., Davidson, B. E., \& Hillier, A. J. (1995). Sequence analysis of the Lactococccus lactis temperate bacteriophage BK5-T and demonstration that the phage DNA has cohesive ends. Applied and Environmental Microbiology, 61, 4089-4098.

Buist, G., Kok, J., Leenhouts, K. J., Dabrowska, M., Venema, G., \& Haandrikman, A. (1995a). Molecular cloning and nucleotide sequence of the gene encoding the major peptidoglycan hydrolase of Lactococcus lactis, a muramidase needed for cell separation. Journal of Bacteriology, 177, 1554-1563.

Buist, G., Venema, G., \& Kok, J. (1998). Autolysis of Lactococcus lactis is influenced by proteolysis. Journal of Bacteriology, 180, 5947-5953.

Buist, G., Venema, G., Kok, J., \& Ledeboer, A. (1995b). Process for the lysis of a culture of lactic acid bacteria by means of a lysin, and uses of the resulting lysed culture. International Patent WO 95/ 31561 .

Bunthof, C. J., van Schalkwijk, S., Meijer, W., Abee, T., \& Hugenholtz, J. (2001). Fluorescent method for monitoring cheese starter permeabilization and lysis. Applied and Environmental Microbiology, 67, 4264-4271.

Cappa, F., \& Bottazzi, V. (1996). Characterization of autolytic enzymes in Lactobacillus casei subsp. casei 1St261. Annali di Microbiologia ed Enzimlogia, 46, 299-310.

Chapot-Chartier, M.-P. (1996). Les autolysines de bactéries lactiques. Le Lait, 76, 91-109.

Chapot-chartier, M.-P., Deniel, C., Rousseau, M., Vassal, L., \& Gripon, J. C. (1994). Autolysis of two strains of Lactococcus lactis during cheese ripening. International Dairy Journal, 4, 251-269.

Chopin, A., Bolotin, A., Sorokin, A., Ehrlich, S. D., \& Chopin, M.-C. (2001). Analysis of six prophages in Lactococus lactis IL1403:different genetic structure of temperate and virulent phage populations. Nucleic Acids Research, 29, 644-651.

Cibik, R., \& Chapot-Chartier, M.-P. (2000). Autolysis of dairy leuconostocs and detection of peptidoglycan hydrolases by renaturing SDS-PAGE. Journal of Applied Microbiology, 89, 862-869.

Cibik, R., \& Chapot-Chartier, M.-P. (2004). Characterization of autolytic enzymes in Lactobacillus pentosus. Letters in Applied Microbiology, 38, 453-459.

Cibik, R., Tailliez, P., Langella, P., \& Chapot-Chartier, M.-P. (2001). Identification of Mur, an atypical peptidoglycan hydrolase derived from Leuconostoc citreum. Applied and Environmental Microbiology, 67, 858-864.

Collins, Y. F., McSweeney, P. L. H., \& Wilkinson, M. (2003). Evidence of a relationship between autolysis of starter bacteria and lipolysis in Cheddar cheese during ripening. Journal of Dairy Research, 70, 105-113.

Crow, V. L., Coolbear, T., Gopal, P. K., Martley, F. G., McKay, L. L., \& Riepe, H. (1995a). The role of autolysis of lactic acid bacteria in the ripening of cheese. International Dairy Journal, 5, 855-875.

Crow, V. L., Curry, B., \& Hayes, M. (2001). The ecology of non starter lactic acid bacteria (NSLAB) and their use as adjuncts in New Zealand Cheddar. International Dairy Journal, 11, 275-283.

Crow, V. L., Martley, F. G., Coolbear, T., \& Roundhill, S. J. (1995b). The influence of phage-assisted lysis of Lactococcus lactis subsp lactis ML8 on Cheddar cheese ripening. International Dairy Journal, 5, 451-472.

Delcour, J., Ferain, T., Deghorain, M., Palumbo, E., \& Hols, P. (1999). The biosynthesis and functionality of the cell wall of lactic acid bacteria. Antonie Van Leeuwenhoek, 76, 159-184.

Desiere, F., Pridmore, R. D., \& Brüssow, H. (2000). Comparative genomics of the late gene cluster from Lactobacillus phages. Virology, 275, 294-305.

Deutsch, S. M., Ferain, T., Delcour, J., \& Lortal, S. (2002). Lysis of lysogenic strains of Lactobacillus helveticus in Swiss cheeses and concomitant Streptococcus thermophilus lysis. International Dairy Journal, 12, 591-600.

Deutsch, S.-M., Guezenec, S., Piot, M., Foster, S., \& Lortal, S. (2004). Mur-LH, the large spectrum endolysin of Lactobacillus helveticus temperate bacteriophage $\Phi$-0303. Applied Environmental Microbiology, 70, 96-103.

Deutsch, S.-M., Neveu, A., Guezenec, S., Ritzenhaler, P., \& Lortal, S. (2003). Early lysis of Lactobacillus helveticus CNRZ303 in Swiss cheese is not prophage-related. International Journal of Food Microbiology, 81, 147-157.

Feirtag, J. M., \& McKay, L. L. (1987). Isolation of Streptococcus lactis $\mathrm{C} 2$ mutants selected for temperature sensitivity and potential use in cheese manufacture. Journal of Dairy Science, 70, 1773-1778 
Fernandez de Palenzia, P., de la Plaza, M., Mohedano, M. L., Martinez-Cuesta, M. C., Requena, T., Lopez, P., \& Pelaez, C. (2004). Enhancement of 2-methylbutanal formation in cheese by using fluorescently tagged lacticin 3147 producing Lactococcus lactis strain. International Journal of Food Microbiology, 93, 335-347.

Fox, P. F., Wallace, J. M., Morgan, S., Lynch, C. M., Niland, E. J., \& Tobin, J. (1996). Acceleration of cheese ripening. Antonie van Leeuvenhoek, 70, 271-297.

Gagnaire, V., Lortal, S., \& Leonil, J. (1998). Free active peptidases are evidenced in Emmental juices extracted before the warm room ripening. Journal of Dairy Science, 65, 119-128.

Gagnaire, V., Piot, M., Camier, B., Vissers, J. P. C., Jan, G., \& Léonil, J. (2004). Survey of bacterial proteins released in cheese: a proteomic approach. International Journal of Food Microbiology, 94, 185-201.

Gasson, M. J. (1994). Method of making cheese using viral enzymes. Patent 5360617.

Gasson, M. J. (1996). Lytic systems in lactic acid bacteria and their bacteriophages. Antonie van Leeuwenhoek, 70, 47-159.

Gopal, P. K., \& Crow, V. L. (1993). Characterization of loosely associated material from cell surface of Lactococcus lactis subsp. cremoris $\mathrm{E} 8$ and its phage-resistant variant strain 398. Applied and Environmental Microbiology, 59, 3177-3182.

Govindasamy-Lucey, S., Gopal, P. K., Sullivan, P. A., \& Pillidge, C. (2000). Varying influence of the autolysin, $N$-acetyl muramidase, and the cell envelope proteinase on the rate of autolysis of six commercial Lactococcus lactis cheese starter bacteria grown in milk. Journal of Dairy Research, 67, 585-596.

Hannon, J. A., Deutsch, S.-M., Madec, M.-N., Gassi, J.-Y., ChapotChartier, M.-P., \& Lortal, S. (2004). Lysis in UF-cheese: differential behavior of lactococci and thermophilic lactobacilli. International Dairy Journal, in press.

Hannon, J. A., Wilkinson, M. G., Delahunty, C. M., Wallace, J. M., Morrissey, P. A., \& Beresford, T. P. (2003). Use of autolytic starter systems to accelerate the ripening of Cheddar cheese. International Dairy Journal, 13, 313-323.

Heinrich, B., Binisshofer, B., \& Bläsi, U. (1995). Primary structure and functional analysis of the lysis genes of Lactobacillus gasseri bacteriophage $\Phi$ adh. Journal of Bacteriology, 177, 723-732.

Hickey, R. M., Ross, R. P., \& Hill, C. (2004). Controlled autolysis and enzyme release in a recombinant lactococcal strain expressing the metalloendopeptidase enterolysin A. Applied and Environmental Microbiology, 70, 1744-1748.

Höltje, J. V. (1995). From growth to autolysis: the murein hydrolases in E. coli. Archives of Microbiology, 164, 243-254.

Huard, C., Miranda, G., Redko, Y., Wessner, F., Foster, S., \& Chapot-Chartier, M.-P. (2004). Analysis of the peptidoglycan hydrolase complement of Lactococcus lactis: identification of a third N-acetylglucosaminidase, AcmC. Applied and Environmental Microbiology, 70, 3493-3499.

Huard, C., Miranda, G., Wessner, F., Bolotin, A., Hansen, J., Foster, S., \& Chapot-Chartier, M.-P. (2003). Characterization of AcmB, an $\mathrm{N}$-acetylglucosaminidase autolysin from Lactococcus lactis. Microbiology, 149, 695-705.

Husson-Kao, C., Mengaud, J., Benbadis, L., \& Chapot-Chartier, M.P. (2000a). Mur1, a Streptococcus thermophilus peptidoglycan hydrolase devoid of a specific cell wall binding domain. FEMS Microbiology Letters, 187, 69-76.

Husson-Kao, C., Mengaud, J., Cesselin, B., Van Sinderen, D., Gripon, J.-C., Benbadis, L., \& Chapot-Chartier, M.-P. (2000b). The Streptococcus thermophilus autolytic phenotype results from a leaky prophage. Applied and Environmental Microbiology, 66, 558-565.

Husson-Kao, C., Mengaud, J., Gripon, J.-C., Benbadis, L., \& ChapotChartier, M.-P. (1999). The autolysis of Streptococcus thermophilus
DN-001065 is triggered by several food-grade environmental factor. International Dairy Journal, 9, 715-723.

Kakikawa, M., Yokoi, K. J., Kimoto, H., Nakano, M., Kawasaki, K. I., Taketo, A., \& Kodaira, K.-I. (2002). Molecular analysis of the lysis protein Lys encoded by Lactobacillus plantarum phage $\Phi \mathrm{gle}$. Gene, 299, 227-234.

Klein, N., \& Lortal, S. (1999). Attenuated starters: a review. International Dairy Journal, 9, 751-762.

Kunji, E. R. S., Mierau, I., Hagting, A., Poolman, B., \& Konings, W. N. (1996). The proteolytic systems of lactic acid bacteria. Antonie van Leeuwenhoek, 70, 187-221.

Law, B. A., Sharpe, E., \& Reiter, B. (1974). The release of intracellular dipeptidase from starter streptococci during Cheddar cheese ripening. Journal of Dairy Research, 41, 137-146.

Lepeuple, A.-S., van Gemert, E., \& Chapot-Chartier, M.-P. (1998a). Analysis of the bacteriolytic enzymes of the autolytic Lactococcus lactis subsp. cremoris strain AM2 by renaturing polyacrylamide gel electrophoresis: identification of a prophage encoded enzyme. Applied and Environmental Microbiology, 64, $4142-4148$.

Lepeuple, A.-S., Vassal, L., Delacroix-Buchet, A., Gripon, J.-C., \& Chapot-Chartier, M.-P. (1998b). Involvement of a prophage in the lysis of Lactococcus lactis subsp. cremoris AM2 during cheese ripening. International Dairy Journal, 8, 667-674.

Lemee, R., Lortal, S., Cesselin, B., \& van Heijenoort, J. (1994). Involvement of an $\mathrm{N}$-acetyl-glucosaminidase in autolyis of Propionibacterium freudenreichii. Applied and Environmental Microbiology, 60, 4351-4358.

Liu, S. Q., Holland, R., \& Crow, V. L. (2003). Ester synthesis in an aqueous environment by Streptococcus thermophilus and other dairy lactic acid bacteria. Applied Microbiology and Biotechnology, $63,81-88$.

Lortal, S. (2004). Cheeses made from thermophilic lactic acid bacteria. In H. Hui, L. M. Goddik, A. S. Hansen, \& W. K. Josephsen (Eds.), Handbook of food and beverage fermentation technology. Chapter 16. New York: Marcel Dekker.

Lortal, S., Lemée, R., \& Valence, F. (1997a). Autolysis of thermophilic lactobacilli and dairy propionibacteria: a review. Le Lait, 77, 135-150.

Lortal, S., Valence, F., Bizet, C., \& Maubois, J.-L. (1997b). Electrophoretic pattern of peptidoglycan hydrolases, a new tool for bacterial species identification: application to 10 Lactobacillus species. Research in Microbiology, 148, 461-474.

Lucchini, S., Desiere, F., \& Brüssow, H. (1999). The genetic relationship between virulent and temperate Streptococcus thermophilus bacteriophages: whole genome comparison of cos-site phages Sfil 19 and Sfi21. Virology, 260, 232-243.

Madsen, S. M., Mills, D., Djordjevic, G., Israelsen, H., \& Klaenhammer, T. R. (2001). Analysis of the genetic switch and replication region of a P335-type bacteriophage with an obligate lytic lifestyle on Lactococcus lactis. Applied and Environmental Microbiology, 67, $1128-1139$

Martinez-Cuesta, M. C., Kok, J., Herranz, E., Pelaez, C., Requena, T., \& Buist, G. (2000). Requirement of autolytic activity for bacteriocin-induced lysis. Applied and Environmental Microbiology, 66, 3174-3179.

Martinez-Cuesta, M. C., Pelaez, C., Juraez, M., \& Requena, T. (1997). Autolysis of Lactococcus lactis subsp. lactis and Lactobacillus casei. Cell lysis-induced by a crude bacteriocin. International Journal of Food Microbiology, 38, 125-131.

Martinez-Cuesta, M. C., Pelaez, C., Juraez, M., \& Requena, T. (2002). Effect of bacteriocin-induced cell damage on the branched-chain amino acid transamination by Lactococcus lactis. FEMS Microbiology Letters, 217, 109-113. 
Meijer, W., Dobbebbar, C., \& Hugenholtz, J. (1998). Thermoinducible lysis in Lactococcus lactis subsp. cremoris SK110: implications for cheese ripening. International Dairy Journal, 8, 275-280.

Meyer, J., \& Spahni, A. (1998). Influence of X-prolyl-dipeptidylaminopeptidase of Lactobacillus delbrueckii subsp. lactis on proteolysis and taste of Swiss Gruyère cheese. Milchwissenschaft, 53, 153-449.

Morgan, S., O'Sullivan, L., Ross, P., \& Hill, C. (2002). The design of a three strains starter system for Cheddar cheese manufacture exploiting bacteriocin-induced starter lysis. International Dairy Journal, 12, 985-993.

Morgan, S., Ross, P., \& Hill, C. (1997). Increasing starter cell lysis in Cheddar cheese using a bacteriocin-producing adjunct. Journal of Dairy Science, 80, 1-10.

Moscovo, M., \& Suarez, J. E. (2000). Characterization of the DNA replication module of bacteriophage and use of its origin of replication as a defense against infection during milk fermentation by Lactobacillus casei. Virology, 273, 101-111.

Mou, L., Sullivan, J. J., \& Jago, G. R. (1976). Autolysis of Streptococcus cremoris. Journal of Dairy Research, 43, 275-282.

Niven, G. W., \& Mulholland, F. (1998). Cell membrane integrity and lysis in Lactococcus lactis: the detection of a population of permeable cells in post-logarithmic phase cultures. Journal of Applied Microbiology, 44, 90-96.

O'Donovan, C. M., Wilkinson, M. G., Guinee, T. P., \& Fox, P. F. (1996). An investigation of the autolytic properties of three lactococcal strains during cheese ripening. International Dairy Journal, 6, 1149-1165.

O'Sullivan, D., Ross, P., Fitzgerald, G. F., \& Coffey, A. (2001). Investigation of the relationship between lysogeny and lysis of Lactococcus lactis in cheese using prophage-targeted PCR. Applied and Environmental Microbiology, 66, 2192-2198.

O’Sullivan, L., Morgan, S. M., Ross, R. P., \& Hill, C. (2002). Elevated enzyme release from lactococcal starter cultures on exposure to the lantibiotic lacticin 481, produced by Lactococcus lactis DPC5552. Journal of Dairy Science, 85, 2130-2140.

O’Sullivan, L., Ross, R. P., \& Hill, C. (2003). A lacticin 481-producing adjunct culture increases starter lysis while inhibiting nonstarter lactic acid bacteria proliferation during Cheddar cheese ripening. Journal of Applied Microbiology, 95, 1235-1241.

Østlie, H. M., Vegarud, G., \& Langsrud, T. (1995). Autolysis of lactococci: detection of lytic enzymes by polyacrylamide gel electrophoresis and characterization in buffer systems. Applied and Environmental Microbiology, 61, 3598-3603.

Pillidge, C. J., Crow, V. L., Coolbear, T., \& Reid, J. R. (2003). Exchanging lactocepin plasmids in lactococcal starters to study bitterness development in Gouda cheese: a preliminary investigation. International Dairy Journal, 13, 345-354.

Pillidge, C. J., Govindasamy-Lucey, S., Gopal, P. K., \& Crow, V. L. (1998). The major lactococcal cell wall autolysin AcmA does not determine the rate of autolysis of Lactococcus lactis subsp. cremoris 2250 in Cheddar cheese. International Dairy Journal, 8 , 843-850.

Pillidge, C. J., Rallabhandi, P. S. V. S., Tong, X. Z., Gopal, P. K., Farley, P. C., \& Sullivan, P. A. (2002). Autolysis of Lactococcus lactis. International Dairy Journal, 12, 133-140.

Poquet, I., Saint, V., Seznec, E., Simoens, N., Bolotin, A., \& Gruss, A. (2000). HtrA is the unique housekeeping protease in Lactococcus lactis and is required for natural protein processing. Molecular Microbiology, 35, 1042-1051.

Riepe, H. R., Pillidge, C. J., Gopal, P. K., \& McKay, L. (1997). Characterization of the highly autolytic Lactococcus lactis subsp. cremoris strains CO and 2250. Applied and Environmental Microbiology, 63, 3757-3763. de Ruyter, P. G., Kuipers, O. P., Meijer, W. C., \& de Vos, W. M. (1997). Food-grade controlled lysis of Lactococcus lactis for accelerated cheese ripening. Nature Biotechnology, 15, 976-979.

Saboya, L., Goudedranche, H., Maubois, J. L., Lerayer, A. L. S., \& Lortal, S. (2001). Impact of broken cells of lactococci or propionibacteria on the ripening of Saint-Paulin UF-cheeses: extent of proteolysis and GC-MS profiles. Le Lait, 81, 699-713.

Sallami, L., Kheadr, E. E., Fliss, I., \& Vuillemard, J.-C. (2004). Impact of autolytic, proteolytic and nisin-producing adjunct cultures on biochemical and textural properties of Cheddar cheese. Journal of Dairy Science, 87, 1585-1594.

Sandberg, E., Haglund, E., \& Barthel, C. (1930). L'analyse du jus de fromage comme moyen de déterminer le degré de maturation. Le Lait, 10, 1-21.

Sanders, J. W., Venema, G., \& Kok, J. (1999). Environmental stress responses in Lactococcus lactis. FEMS Microbiology Review, 23, 483-501.

Sheehan, M. M., Stanley, E., Fitzgerald, G. F., \& van Sinderen, D. (1999). Identification and characterization of a lysis module present in large proportion of bacteriophages infecting Streptococcus thermophilus. Applied and Environmental Microbiology, 65, 569-577.

Shockman, G. D., \& Höltje, J.-V. (1994). Microbial peptidoglycan (murein) hydrolases. In J.-M. Ghuysen, \& R. Hakenbeck (Eds.), Bacterial cell wall — new comprehensive biochemistry (pp. 131-166). London: Elsevier.

Smith, T. J., Blackman, S. A., \& Foster, S. J. (2000). Autolysins of Bacillus subtilis: multiple enzymes with multiple functions. Microbiology, 146, 249-262.

Steen, A., Buist, G., Horsburgh, G., Foster, S., Kuipers, O., \& Kok, J. (2001). AcmA is a glucosaminidase. Cork, Ireland: EuroLAB Conference July 3-6, 2001 .

Steen, A., Buist, G., Leenhouts, K. J., El Khattabi, M., Grijpstra, F., Zomer, A. L., Venema, G., Kuipers, O. P., \& Kok, J. (2003). Cell wall attachment of a widely distributed peptidoglycan binding domain is hindered by cell wall constituents. Journal of Biological Chemistry, 278, 23874-23881.

Tuler, T. R., Callanan, M. J., \& Klaenhammer, T. R. (2002). Overexpression of peptidases in Lactococccus and evaluation of their release from leaky cells. Journal of Dairy Scence, 85, 2438-2450.

Valence, F., Deutsch, S.-M., Richoux, R., Gagnaire, V., \& Lortal, S. (2000). Autolysis and related proteolysis in Swiss cheese for two Lactobacillus helveticus strains. Journal of Dairy Research, 67, 261-271.

Valence, F., \& Lortal, S. (1995). Zymogram and preliminary characterization of Lactobacillus helveticus autolysins. Applied and Environmental Microbiology, 61, 3391-3398.

Valence, F., Richoux, R., Thierry, A., Palva, A., \& Lortal, S. (1998). Autolysis of Lactobacillus helveticus and Propionibacterium freundenreichii in Swiss cheeses: first evidence by using species-specific lysis markers. Journal of Dairy Research, 65, 609-620.

Van Sinderen, D., Karsens, H., Kok, J., Terpstra, P., Ruiters, M. H. J., Venema, G., \& Nauta, A. (1996). Sequence analysis and molecular characterization of the temperate lactococcal bacteriophage rlt. Molecular Microbiology, 19, 1343-1355.

Vegarud, G., Castberg, H. B., \& Langsrud, T. (1983). Autolysis of group $\mathrm{N}$ streptococci. Effects of media composition modifications and temperature. Journal of Dairy Science, 66, 2294-2302.

Walker, S. A., \& Klaenhammer, T. (2001). Leaky Lactococcus cultures that externalize enzymes and antigens independently of culture lysis and secretion and export pathways. Applied and Environmental Microbiology, 67, 251-259.

Wiederholt, K. M., \& Steele, J. L. (1993). Prophage curing and partial characterization of temperate bacteriophages from thermolytic 
strains of Lactococcus lactis ssp. cremoris. Journal of Dairy Science, 76, 921-930.

Wilkinson, M. G., Guinee, T. P., \& Fox, P. F. (1994a). Factors which may influence the determination of autolysis of starter bacteria during Cheddar cheese ripening. International Dairy Journal, 4, 141-160.

Wilkinson, M. G., Guinee, T. P., O'Callaghan, D. M., \& Fox, P. F. (1994b). Autolysis and proteolysis in different strains of starter bacteria during Cheddar cheese ripening. Journal of Dairy Research, 61, 249-262.
Wilkinson, M. G., Guinee, T. P., O' Callaghan, D. M., \& Fox, P. F. (1995). Effect of cooking temperature on the autolysis of starter, Lactococcus lactis subsp. cremoris AM2, and the maturation of Cheddar cheese. Milchwissenschaft, 50, 376-380.

Yvon, M., Berthelot, S., \& Gripon, J. C. (1998). Adding $\alpha$-ketoglutarate to semi-hard cheese curd highly enhances the conversion of amino acids to aroma compounds. International Dairy Journal, 8, 889-898.

Yvon, M., \& Rijnen, L. (2001). Cheese flavour formation by amino acid catabolism. International Dairy Journal, 11, 185-201. 